\title{
Relationship between the Transformational Leadership Style and Communication Climate in the Intensive Care Unit: \\ A Comparative Study
}

\author{
Nevine Hassan Abd-Elaal, Lecturer \\ Nursing Administration, Faculty of Nursing, Damanhour University \\ Wafaa Hassan Moustafa, Lecturer \\ Nursing Administration, Faculty of Nursing, Damanhour University
}

\begin{abstract}
Transformational leadership styles and communication climate in the intensive care units (I.C.US) foster innovation behaviors of staff nurses in organization, in particular, in the I.C.Us. Objective: To assess and compare the relationship of transformational leadership style and communication climate. Setting: I.C.Us (Damanhour National Medical Institute (DNMI) and Alexandria Main University Hospital (AMUH). Subjects: 141 staff nurses who are working in the previously mentioned two hospitals: 62 staff nurses at DNMI, 79 staff nurses at AMUH. Tools: Tool I: Multifactor leadership questionnaire (MLQ), Tool II: communication climate inventory questionnaire (CCIQ). Results: No significant difference were found in both total level of: transformational leadership style and communication climate in the two hospitals. Moreover, in DNMI had proved to be significantly positive strong correlation between total transformational leadership style with total communication climate and in AMUH had proved to be significantly moderate correlation between total transformational leadership style with total communication climate. Conclusion: a significant positive strong correlation between total transformational leadership style with total communication climate in DNMI while a significant positive moderate correlation between total transformational leadership style with total communication climate in AMUH. Recommendations: In-service training program should be conducted periodically for head nurses and staff nurses about different leadership styles, its importance and its impact in the communication climate in the intensive care units.
\end{abstract}

Keywords: Transformational Leadership, Communication Climate.

\section{Introduction}

Benign prostate hypertrophy $(\mathrm{BPH})$ is the transformational leadership manage dayto-day operation and create strategies for the organization, department and the work team to operate on a high level of performance. It focus on team-building, motivation and collaboration with individual at different level, while providing the opportunities to personal and professional growth to achieve the goals of the organization ${ }^{(1,2)}$.

Bass \& Avolio (1994), Bass \& Riggo
(2008) characterized transformational leadership as being composed of four unique but interrelated behavioral components: charisma, inspiration, intellectual stimulation and individualized consideration $^{(3,4)}$. Charisma: arouses strong emotions from followers and identification with the leader because leaders act as strong role models for followers, display very high moral standards ${ }^{(5)}$. Inspiration: leader articulates a vision that is appealing and inspiring to followers. Leader challenges followers with high standards, communicates optimism about future goals, and provides meaning for the task at hand ${ }^{(6)}$. Intellectual stimulation: increases 
awareness of problems and influences followers to view problems from a new point of view. They are stimulated to be creative and innovative and also to challenge their own beliefs and values, and those of their leaders and their organization $^{(7)}$. Individualized

consideration: shows how much a leader gives personal attention to followers and the degree to which the leader provides support, encouragement, coaching, delegation, advice and feedback ${ }^{(5)}$.

Byrne \& Rees (2006), Charbonnier \& Akremi (2010) stated that the utilization of transformational leadership increase found the individuals satisfaction, enhance their team performance and create a supportive communication climate ${ }^{(8,9)}$.

Communication climate is the invisible concept of how communication is conducted within a work place environment ${ }^{(10)}$. It is a paramount important in an organization as it contributes to its effectiveness and success. Also, it influence the atmosphere in the organization which either encourages or hinders the communication among staff at the work place $^{(11)}$. An open clear communication climate tends to open healthy staff relations, good job performance, increase productivity and constructive conflict resolution ${ }^{(10)}$. On the other hand, a poor communication climate inhibits cooperation between staff member and frequently contributes to the occurrence of errors in the work place ${ }^{(12)}$. The climate in which communication occurs is a result of how staff at work perceive and react to factors such as; openness communication, participation in decision making and adequacy information through communication methods by using a verbal and nonverbal, formal and informal communication and listening skills: can be defensive or supportive ${ }^{(13-15)}$.

Factors which hold the major source of influence over communication climate are: ${ }^{(16)}$ Openess communication climate is the situation where there is free flow of information such as upward commutation horizontally and vertically ${ }^{(17)}$. It also includes a willingness to listen openly and to react honestly to the message of others ${ }^{(18)}$. Participative in decision making the managers still have the final responsibility for making decisions and answering for them, but employees who are affected by those decisions are actively sought to provide observation, analysis, suggestions and recommendations in the executive decision making process ${ }^{(19)}$. Adequacy information versus information overload creates an apparent paradox. Just providing information which is not sufficient to satisfy staff needs ${ }^{(20)}$.

The Intensive care environment is characterized by: uncertainty, global turbulence, and organizational instability which call for the need of transformational leader in all levels of health care organization. Transformational leaders, in particular, who are considered as powerful agents in transforming the work in the intensive care unit. Communication climate which is characterized by an articulating a compelling vision of a safe communication environment, serving as role models for nurses, encouraging support and recognizing their individual needs and contribution $^{(21)}$. Such a communication climate provide nurses with a strong motivational forces to deliver better nursing knowledge and skills ${ }^{(22)}$.

A study in Singapore (2009) examined the influence of leadership styles on communication climate: A case study of madrasahs' management. It demonstrated that, people-oriented leadership was correlated with open communication climate whilst task-oriented leadership style to be was correlated with close communication climate ${ }^{(17)}$. Also, Czech and Forward (2010) examined the communication, leadership, and job satisfaction: perspectives on supervisorsubordinate relationships. It demonstrated that, there were strong, predictive relationships between the positive communication behaviors and workers 
perceptions of supervisors effectiveness, relational satisfaction, and employees job satisfaction $^{(23)}$.

Moreover, Gross (2014) studied the impact of transformational leadership, climate and trust in cross-functional teams. It concluded that, transformational leadership enhances the underpinning of team cohesiveness at the team level and it creates the ability to produce efficiently multiple projects. The climate was not a major factor in considering the overall effectiveness and cohesiveness of leading across- functional teams ${ }^{(24)}$.

In Egypt, Gheith (2010) examined that Reconstructing organization culture through enforcing head nurses transformational leadership style at El Mansoura Faculty of Nursing. It concluded that a greater awareness of transformational leadership style of head nurses which succeed in raising staff nurses perception of their organizational culture ${ }^{(25)}$.

Also, a study was done by Mohamed and colleagues (2013) to assess the communication climate at the Main Assiut University Hospital. It showed that, the highest mean scores were found among nurses in provisionalism, description, and empathy respectively. While, among employees were found in description, problem-oriented, and empathy respectively with statistically significant differences among the studied subjects as regard to supportive communication climate factors $^{(26)}$. Furthermore, Moustafa (2013) studied the effect of transformational leadership style training program for head nurses on the quality of work life of staff nurses. It concluded that, the head nurses transformational leaderships style training program had a positive effect on the staff nurses quality of work life (empowerment, job satisfaction and organizational commitment) ${ }^{(27)}$.

It was observed during the experiences in these two hospitals that the work place, that communication climate was improper in the intensive care unit between staff nurses and the head nurses this may be due to that the head nurses in these units are not implementing the transformational style of leadership. This study was conducted to identify the relationship between the transformational leadership style and communication climate in the intensive Care Unit. It is hoped that this study will enhance the head nurses relationships between the staff nurses and head nurses utilizing this style of leadership which in-turn will improve the communication climate.

\section{Aims of the Study}

The current study aims to:

- Assess the relationship between transformational leadership style and a communication climate as perceived by staff nurses in the I.C.Us. at Damanhour National Medical Institute (DNMI) and Alexandria Main University Hospital (AMUH).

- Compare the relationship between transformational leadership style and a communication climate as perceived by staff nurses in the I.C.Us. at Damanhour National Medical Institute (DNMI) and Alexandria Main University Hospital (AMUH).

\section{Research Questions:}

- Is there a relationship between transformational leadership style and communication climate in both hospitals?

- Is there a difference between transformational leadership style and communication climate in both hospitals? 


\section{Materials and Method}

Materials

Design: A comparative descriptive correlational study was utilized.

Setting: The study was carried out in all intensive care units $(n=6)$ at Damanhour National Medical Institute namely; emergency dialysis, emergency care, coronary care $(\mathrm{CCU})$, neurosurgery, open heart surgery and general I.C.U. and its capacity is 45 beds. The same intensive care units $(n=6)$ at Alexandria Main University and its capacity is 62 beds.

Subjects: The study comprised 141 staff nurses who are working in the previously mentioned two hospitals: $n=62$ staff nurses in DNMI and $n=79$ staff nurse in AMUH who were available at the time of data collection and were interested in participating in the study.

Tools: Two tools were used in this study:

\section{Tool I: Multifactor Leadership} Questionnaire (MLQ)

It was developed based on Bass (1995) $)^{(28)}$ and the review of related literature ${ }^{(5-8)}$ to determine head nurses' transformational leadership style as perceived by staff nurses. It contains 31 sub-items grouped under four main items namely: charisma (7 sub-items), inspiration (3 sub-items), intellectual stimulation (11 sub-items) and individualized consideration (10 sub-items).

Responses of staff nurses were measured on 3-point likert scale ranged from " 1 " never, " 2 " sometimes and "3" always.

\section{Tool II: Communication Climate} Inventory Questionnaire

It was used by the researcher to determine the quantity and quality of the adolescent's food intake in the last 24 hours.

It was developed by the researchers based on the work of Costigan and Schmeidler $(1984)^{(13-14)}$ and the review of related literature ${ }^{(29-32)}$. It was designed to asses communication climate factors used by head nurses' in the I.C.Us as perceived by staff nurses. It contains 34 sub-items grouped under three main items namely: communication openness (16 sub-items), participation in decision making (7 subitems), information adequacy (11 subitems).

Responses of staff nurses were measured on 3-point likert scale ranged from "1" disagree, " 2 " uncertain and " 3 " agree. Negative reversed statements were reversed coded before the analysis.

In addition, a demographic characteristics of staff nurses such as: name of hospital, type of I.C.Us., age, years of nursing experience, educational qualifications, years of experience in nursing units and marital status.

\section{Method}

1- An official permission was obtained from the two hospital authorities in the identified setting to collect the necessary data.

2- Tools I, and tool II were tested for its content validity by five experts in the field of the study and accordingly, necessary modifications were done.

3- Tool I were tested for its reliability to measure the internal consistency of the items using the cronbach`s alpha. It proved to be: charisma was 0.841 , inspiration was 0.778 , intellectual stimulation was 0.947 and individualized consideration was 0.739

4- Tool II were tested for its reliability to measure the internal consistency of the items using the cronbach`s alpha. It proved to be: communication openness was 0.881 , information adequacy was 0.769 and participation in decision making was 0.827

5- A pilot study was carried out $10 \%$ of the subjects $(n=14)$ on staff nurses working in the nursing units at 
Damanhour national medical institute. They were conveniently selected and were not included in the study subjects. It was used to ensure the clarity of the tools, identify obstacles that may be encountered during data collection and estimate the time needed to fill the questionnaires.

6- Data was collected from staff nurses $(\mathrm{N}=141)$ using tools I, II, they were asked to fill the tools independently. Each subject took a period around 45 minutes. It took a period of four weeks period from 30/11/2014 to 1/1/2015.

\section{Ethical considerations:}

- The purpose of the study was explained to all staff nurses.

- Confidentiality and anonymity were maintained and their rights to withdraw from the study at any time was explained and ensured.

\section{Statistical Analysis}

After data were collected it was revised, coded and fed to statistical software SPSS IBM version 20. The given graphs were constructed using Microsoft excel software. All statistical analysis were done using two tailed tests and alpha error of 0.05. All items concerning leadership style and communication climate, discrete scores for items were summed together and score \% was calculated by dividing the actual score by maximum score then a participant with a score $\%$ below $33.3 \%$ were considered to have weak level while those who had a score $\%>66.6 \%$ were classified to have good level.

Descriptive statistics in the form of frequencies and percent were used to describe the categorical data variables. To test for Association between sample characteristics and their levels (leadership style and communication), Pearson's chisquare test was used but if the distribution cells have a small values, exact tests were the used. Pearson correlation coefficient was used to test the nature and degree of relation between leadership styles and commutation level. Weak correlation for rho less than 0.25 , intermediate correlation for rho of value between $0.25-0.74$ and strong correlation for values between 0.75 0.99 .

\section{Results}

Table (1) reveals the demographic characteristics of staff nurses. As regards, types of I.C.Us the highest percentages was $29 \%$ in the CCU at DNMI and $30.4 \%$ in the General I.C.Us at AMUN while, the lowest percentage was $8.1 \%$ in the emergency care unit in DNMI and $7.6 \%$ in the Emergency dialysis in AMUH with a significant difference $\mathrm{P}=0.031$. In relation to staff nurses age the highest percentage was $24.2 \%$ in age group 35 years to less than 40 years at DMNI and $25.3 \%$ in age group 25 years to less than 30 years at AMUH. On the other hand the lowest percentages were $8.1 \%$ in age group 40 years and more at DMNI and $15.2 \%$ was in age group 30 years to less than 35 years at AMUH with no significant difference $\mathrm{P}=0.228$.

Concerning, staff nurses educational qualifications the highest percentages was $46.8 \%, 51.9 \%$ respectively who have secondary nursing school diploma in both hospitals while the lowest percentages $25.8 \%$ of who hold bachelor science degree in nursing at DMNI and $22.8 \%$ who have technical institute diploma at AMUH with no significant difference $\mathrm{P}=0.784$.

According to, marital status the highest percentages were $74.2 \%, \quad 81.0 \%$ respectively were married in the two hospitals compared to $3.2 \%$ and $2.5 \%$ respectively who were widow in both hospitals with no significant difference $\mathrm{P}=0.623$.

As regards, the years of experience in nursing there was a significant difference $\mathrm{P}=0.007$ and the highest percentages 
(50.0\%, $73.4 \%$ respectively) had 10 and more years of experience in nursing at the two hospitals while $24.2 \%$ was the lowest who have five years to less than 10 years of experience in nursing at DMNI and $8.9 \%$ who have one year to less than five years of experience in nursing at AMUH.

Also, in relation to years of experience in nursing there was a significant difference $\mathrm{P}=0.011$ and the highest percentage $38.7 \%$, $62.0 \%$ respectively of staff nurses who had 10 and more years of experience in nursing unit in both hospitals. On the other hand, $25.8 \%$ of staff nurses who have five to less than 10 years of experience in nursing unit at DNMI and $16.5 \%$ was the lowest percentage of staff nurses who have one to less than five years of experience in the nursing unit at AMUH.

Table (2) shows that $21.0 \%, 22.8 \%$ of the staff nurses perceive the overall level of transformational leadership style behavioral components of head nurses as good in both hospitals (DMNI and AMUH respectively) with no significant difference where $(p=0.796)$. Regarding staff nurses perception about head nurses transformational leadership style behavioral components at DMNI it could be ranked in descending order in relation to good level as: the first was inspiration $(38.7 \%)$, the second was charisma $(27.4 \%)$, the third was intellectual stimulation $(24.2 \%)$ and the last one was individualized consideration $(21.0 \%)$. Concerning AMUH it could be ranked in descending order in relation to good level as: inspiration (41.8\%), intellectual stimulation and individualized consideration were the same percent $(27.8 \%)$ and the last one was charisma $(24.1 \%)$.

Table (3) describes that $11.3 \%$ and $19.0 \%$ of the staff nurses perceive the overall total level of communication climate factors as good in both hospitals (DNMI, AMUH respectively) with no significant difference where $(\mathrm{P}=0.211)$. As regards DNMI it could be ranked in descending order in relation to good level the first was participation in decision making (21.0\%), the second was communication openness $(14.5 \%)$ and the last was information adequacy $(9.7 \%)$ While in AMUH, it could be ranked in descending order as participation in decision making $(29.1 \%)$, information adequacy $(20.3 \%)$ and the last one was communication openness (17.7\%).

Table (4) shows that, the good level of head nurses' transformational leadership style behavioral components as perceived by staff nurses at DNMI: in relation to the type of I.C.Us, the highest percentage of staff nurses $(85.7 \%)$ was in the open heart while the lowest percentage $(0.0 \%)$ was in the emergency care unit with a significant difference where $(p=0.001)$. As regards to staff nurses' age, the highest percentage $(30.8 \%)$ in the age group 30 years to less than 35 years, compared to the lowest percentage $(16.7 \%)$ of staff nurses who have 25 years to less than 30 years with no significant difference where $(\mathrm{p}=0.908)$.

Regarding educational qualifications, the highest percentage of staff nurses $(50.0 \%)$ who have bachelor degree of science in nursing compared to $0.0 \%$ of staff nurses who have technical institute diploma with a significant difference where $(\mathrm{p}=0.002)$. According to marital status the highest percentage $(50.0 \%)$ of staff nurses who were widow compared to the lowest percentages (17.4\%) who were married. With no significant difference where $\mathrm{p}=0.394$

Concerning the years of experience in nursing the highest percentage of staff nurses $(33.3 \%)$ who five years to less than 10 years of experience in nursing compared to $16.1 \%$ of staff nurses who had 10 years and more with no significant difference where $(p=0.390)$. Regarding years of experience in the nursing unit, the highest percentage of staff nurses $(25.0 \%)$ who had five years to less than 10 years of experience in the nursing unit compared to $16.7 \%$ of staff nurses who had 10 years and more with no significant difference where $(p=0.792)$. 
Table (5) shows that, the good level of head nurses' transformational leadership style behavioral components as perceived by staff nurses at AMUH: in relation to the type of I.C.U, the highest percentage of staff nurses $(54.5 \%)$ was in the open heart while the lowest percentage $(0.0 \%)$ was in the emergency dialysis with no significant difference where $(p=0.087)$. As regards to staff nurses' age, the highest percentage $(33.3 \%)$ in the age group 40 years and more, compared to the lowest percentage $(16.7 \%)$ who have 30 years to less than 40 years with no significant difference where $\mathrm{p}=0.747$.

Regarding educational qualifications, the highest percentage of staff nurses $(35.0 \%)$ who have bachelor degree of science in nursing compared to $16.7 \%$ of staff nurses who have technical institute diploma with no significant difference where $(p=0.312)$ According to marital status the highest percentage $(53.8 \%)$ of staff nurses who were single compared to $0.0 \%$ who were widow. With a significant difference where $(\mathrm{p}=0.012)$.

Concerning years of experience in nursing the highest percentage of staff nurses $(42.9 \%)$ who have 1 to less than 5 years of experience in nursing compared to 7.1 of staff nurses who have 5 years to less than 10 years of experience in nursing with no significant difference where $(\mathrm{p}=0.164)$. Regarding years of experience in nursing unit, the highest percentage of staff nurses $(24.5 \%)$ who have 10 years and more compared to $17.6 \%$ of staff nurses who have 5 years to less than 10 years of experience in nursing unit. With no significant difference where $(\mathrm{p}=0.845)$.

Table (6) shows that, the good level of communication climate at DNMI: in relation to type of I.C.Us, the highest percentage of staff nurses $(71.4 \%)$ was in open heart while the lowest percentage $(0.0 \%)$ was in emergency dialysis, emergency care unit and in CCU. With a significant difference where $(\mathrm{p}=0.001)$. As regards to staff nurses' age, the highest percentage of staff nurses $(20.0 \%)$ in the age group 40 years and more compared to the lowest percentage $(5.9 \%)$ of staff nurses who have 20 years to less than 25 years with no significant difference where $(\mathrm{p}=0.868)$.

Regarding educational qualifications, the highest percentage of staff nurses $(25.0 \%)$ who have bachelor of science in nursing compared to $0.0 \%$ of staff nurses who have technical institute diploma with a significant difference where $(p=0.050)$. According to marital status the highest percentage $(50.0 \%)$ of staff nurses who were widow compared to the lowest percentages $(8.7 \%)$ who were married with no significant difference where $(\mathrm{p}=0.180)$.

Concerning years of experience in nursing the highest percentage of staff nurses $(20.0 \%)$ who have 5 years to less than 10 years of experience in nursing compared to $6.3 \%$ of staff nurses who have 1 years to less than 5 years with no significant difference where $(\mathrm{p}=0.444)$. Regarding years of experience in the nursing unit, the highest percentage of staff nurses $(12.5 \%)$ who have 5 years to more than 10 years of experience in the nursing unit compared to $9.1 \%$ of staff nurses who have one years to less than five years of experience in the nursing unit. With no significant difference where $(\mathrm{p}=0.921)$.

Table (7) shows that, a good level of communication climate at AMUH: in relation to type of I.C.Us, the highest percentage of staff nurses $(45.5 \%)$ was in open heart while the lowest percentage $(0.0 \%)$ was in emergency dialysis with no significant difference where $(\mathrm{p}=0.081)$. As regards to staff nurses' age, the highest percentage of staff nurses $(25.0 \%)$ in the age group 30 years to less than 35 years, compared to the lowest percentage $(15.0 \%)$ of staff nurses who have 25 years to less than 30 years with no significant difference where $(\mathrm{p}=0.961)$.

Table (8) shows that, a good level of communication climate at AMUH: in 
relation to type of I.C.Us, the highest percentage of staff nurses $(45.5 \%)$ was in open heart while the lowest percentage $(0.0 \%)$ was in emergency dialysis with no significant difference where $(\mathrm{p}=0.081)$. As regards to staff nurses' age, the highest percentage of staff nurses $(25.0 \%)$ in the age group 30 years to less than 35 years, compared to the lowest percentage (15.0\%) of staff nurses who have 25 years to less than 30 years with no significant difference where $(\mathrm{p}=0.961)$.

Regarding educational qualifications, the highest percentage of staff nurses $(40.0 \%)$ who have bachelor of science in nursing compared to $11.1 \%$ of staff nurses who have technical institute diploma with a significant difference where $(p=0.021)$. According to marital status the highest percentage $(61.5 \%)$ of staff nurses who were single compared to the lowest percentages $(0.0 \%)$ who were widow with a significant difference where $(\mathrm{p}=0.001)$.

Concerning years of experience in nursing the highest percentage of staff nurses $(28.6 \%)$ who have one years to less than five years of experience in nursing compared to $17.2 \%$ of staff nurses who have 10 years and more with no significant difference where $(p=0.746)$. Regarding years of experience in the nursing unit, the highest percentage of staff nurses $(23.5 \%)$ who have five years to less than 10 years of experience in the nursing unit compared to $15.4 \%$ of staff nurses who have one years to less than five years of experience in the nursing unit with no significant difference where $(\mathrm{p}=0.839)$.

Table (9) shows correlation between relationship total transformational leadership style with total communication climate at DNMI had proved to be significantly positive strong correlation $\left(\mathrm{r}=0.75^{*}\right)$ while at AMUH had proved to be significantly positive moderate correlation $(\mathrm{r}=0.69 *)$. All other transformational leadership style types of behavior and communication climate methods at the two hospitals were ranged from $\mathrm{r}=0.38^{*}$ (moderate) to $\mathrm{r}=0.76^{*}$ (strong).

\section{Discussion}

Different types of leadership advocate different communication climate to influence staff nurses. Transformational leadership motivates nurses by appealing to their higher-order needs and induces them to transcend self-interest for the sake of the organization $^{(33)}$. Transformational leadership, by definition, evokes all of these predictive, supportive communication climate $^{(34)}$ Transformational leaders foster an open climate where members experience encouragement and vision is communicated to them with their values and concerns in mind ${ }^{(35)}$.

In relation to, the overall head nurses transformational leadership style, the present study revealed that, the lowest percentage was in the good level of head nurses` transformational leadership style than that of the fair level as perceived by staff nurses working in the I.C.Us at the two hospitals with no significant difference. This may be attributed to that, nursing care at I.C.Us is a complex task, where there is a heavy workload, limited number of staff nurses and critical patients conditions of patients; entailing a pressure on the head nurses to consider all staff nurses' individual needs and desires related to work, or to encourage them to find solutions by themselves in a creative way. According to Avolio et al. (2004) the ability of transformational leaders to stimulate followers' intellectual and develop their potentials may directly develop followers' moralities. They believe that they can use their creativities to achieve difficult goals $^{(36)}$. Moreover, Callow (2008) found that there was a significant relationship between individualized consideration and followers' acceptance of goals and high performance $^{(37)}$.

Regarding head nurses'

transformational leadership style types of behaviors, the present study revealed that, 
the highest percentage for the good level was in inspiration behavior at the two hospitals, with no significant difference. This may be attributed to that, the serious work in I.C.Us force head nurses to establish a unit vision, emphasize aims, raise staff nurses' confidence and inspire them to try harder for positive results for the sake of patients and for them. Also, instability of patients' condition increases the contact of head nurse with her staff to work as a team and that increases the humanities among them than those on the units. In this respect, Leithwood (2000) and Stone et al. (2003) stated that the transformational leadership articulates the vision in a clear and appealing manner, and explains how to attain the visions acts confidently and optimistically and expresses confidence in their followers ${ }^{(38,39)}$. Furthmore, Avolio and Bass (2002) stated that transformational leaders inspire and motivate others by providing meaning and challenge to their follower's work, to see the attractive future state while communicating expectations and demonstrating a commitment to shared vision and goals ${ }^{(40)}$.

Concerning the overall communication climate, the present study revealed that, there was the lowest percentage in the good level of communication climate than that of the fair level as perceived by staff nurses at the two hospitals with no significant difference. This may be attributed to that, I.C.Us are characterized by a high level of workrelated stress, hopeless therapeutic cases, volume of work and under-staffing. All these factors may make staff nurses feel not free to express their opinions, voice complaints and offer suggestions to their head nurses in a complete way. Meanwhile, the head nurse may not let them feel that their suggestions and complaints are welcome. In this respect, Barge (2008) stated that, the real work of a leader is not to manage a unit and organizational function but to manage conversations and interpersonal communication, because communication is the essence of leadership itself ${ }^{(41)} 0$ Incontrast Hackman and Johnson (2009) reported that leadership is a communication phenomenon and patterns of communication shape the perceptions subordinate's have of a leader ${ }^{(42)}$.

As regard the communication climate methods used by head nurses, the present study revealed that, the highest percentage for the good level was in participative in decision making method at the two hospitals, with no significant difference. This may be attributed to that the nature of work at the I.C.Us forces staff nurses to be involved directly in decision making. They are trained to take vital decisions at short time especially those related to patients saving life. This result is consistent with Boman and Deal (1997) who found that engagement of followers in the decision making process help in creating a communication climate $^{(43)}$. In this respect, Mohammed and Hussein (2008), stated that nurses at all levels should be provided with communication and consultation with leaders for the purpose of participating in decision making ${ }^{(44)}$.

In relation to the demographic characteristics of staff nurses with head nurses` transformational leadership style and communication climate at DNMI, concerning types of I.C.U the highest percentage of the good level was in the open heart unit and there was a significant relation. This may be attributed to that the open heart unit is a unique practice environment, where provision of effective care requires effective leadership and communication climate that are crucial in order to bring diverse staff together to provide safe care and achieve positive patient outcomes. Avolio and Bass (2002) mentioned that transformational leaders create safer work environment in the unit $^{(40)}$.

As regard to educational qualifications, the current study findings revealed that, the highest percentage of the good level of transformational leadership style and of those the climate was on those who have the 
Bachelor degree of Science in Nursing (B.Sc.N) with a significant difference. This may be attributed to that staff nurses with diploma degree in nursing may feel that, they may face job strain as they may feel difficulties insecure in the relationships with other health care providers. Sheridan et al. (1984) mentioned that, highly qualified nurses evaluate the leadership quality of their superiors positively, further education and training raises nurses expectations towards their superiors and of the work context in which they evolve ${ }^{(45)}$. Moreover, Mitchell (2000) stated that, the level of education was identified as important determinant in the attitudes and behavior of workers. It influences individuals values, wants and needs and makes them think and behave differently ${ }^{(46)}$.

In relation to the demographic characteristics of staff nurses with head nurses` transformational leadership style and communication climate at AMUH, concerning educational qualification, The current study findings revealed that, the highest percentage of the good level of transformational leadership style and of communication climate was in those who have Bachelor of Science degree in Nursing with a significant difference with communication climate. This may be attributed to that staff nurses who have Bacheolar Sciences degree in Nursing have work competency access to information, and opportunities to learn and grow in their work, have a greater sense of selfconfidence, have work competence so, they are in a high need for the head nurse, as a transformational leader, who recognizes and respects which influence workplace interactions and contribute to effective leader-follower communication. In contrast with Nguyen et al. (2003) who stated that, individuals with higher level of education tend to be less satisfied with their job because they have high expectations from the organization ${ }^{(47)}$.

Regarding marital status, the current study findings revealed that, the highest percentage of the good level of transformational leadership style and of communication climate was in the single staff nurses with a significant difference. This may be attributed to that, single staff nurses have less family responsibilities, more time and effort for achieving unit objectives, focusing on excellence in their job through interacting with transformational head nurse and communication climate. In contrast, Mostafa (2005) revealed that, married nurses were more satisfied with their transformational leadership style than unmarried nurses ${ }^{(48)}$.

Concerning, the head nurses' transformational leadership style behavioral components, findings revealed a significant positive strong correlation with communication climate in DNMI and a significant positive moderate correlation with communication climate in AMUH. This may justify the importance and the impact of head nurses transformational leadership style types of behavior on the communication climate in their units "I.C.Us" with staff nurses as perceived by them in both hospitals. The head nurses' as leaders play an important role in the attainment of unit goals as well as the organizational goals by creating a good communication climate in their work units and an internal environment that may influence staff nurses' attitudes, behaviors, motivations, job satisfaction as well as good communication interpersonal relationships with them. These results were consistent with Liao and Chuang (2007) who stated that transformational leaders, are powerful agents in transforming the work unit's communication climate which is better for the organizational behaviors such as articulating a compelling vision of safe communication environment, inspiring enthusiasm and optimism, building trust, mutual respect and serving as role models in a safe environment, encouraging support, recognizing staff needs, hence, fostering a psychologically safe communication climate $^{(49)}$. In this respect, Dvir et al., 
(2002) and Brown \& May (2012) reported that managers behave as transformational leaders in order to increase staff members perceptions of quality work life that contribute a high communication climate in their work ${ }^{(50,51)}$.

\section{Conclusion}

A significant positive strong correlation was found between total transformational leadership style with total communication climate in DNMI. While, a significant positive moderate correlation was found between total transformational leadership style with total communication climate in AMUH.

\section{Recommendations}

a) For nursing service director:

1- In-service training program should be conducted periodically for head nurses and staff nurses about different leadership styles, its importance and its impact in the communication climate in the intensive care units.
2- Encourages the head nurses to utilize the transformational leader in order to establish a positive communication climate.

3- Encourage the head nurses to continue their education in nursing administration specialty to attain all types and latest leadership knowledge and skills which are necessary for their career.

b) For head nurses:

Head nurses should encourage staff nurses to work as a team.

c) For further study:

1- Study to be conducted on the factors which create a positive communication climate such as essential of magnetism, and quality of work life in the two hospitals.

2- Study to assess the relationship between the transformational leadership style and communication climate in the medical and surgical units at two hospitals. 
Table (1): Demographic characteristics of staff nurses at Damanhour National Medical Institute (DNMI) and Alexandria Main University Hospital (AMUH) (n= 141).

\begin{tabular}{|c|c|c|c|c|c|c|}
\hline \multirow{3}{*}{\multicolumn{2}{|c|}{ Demographic Characteristics }} & \multirow{2}{*}{\multicolumn{2}{|c|}{$\begin{array}{c}\text { DNMI } \\
\text { Staff nurses } \\
(\mathrm{n}=62)\end{array}$}} & \multirow{2}{*}{\multicolumn{2}{|c|}{$\begin{array}{c}\text { AMUH } \\
\text { Staff nurse } \\
(n=79)\end{array}$}} & \multirow{3}{*}{$M C P$} \\
\hline & & & & & & \\
\hline & & No & $\%$ & No & $\%$ & \\
\hline \multirow{6}{*}{$\begin{array}{l}\text { Types } \\
\text { I.C.U }\end{array}$} & Emergency dialysis & 10 & 16.1 & 6 & 7.6 & \multirow{6}{*}{$0.031 *$} \\
\hline & Emergency care unit & 5 & 8.1 & 14 & 17.7 & \\
\hline & $\mathrm{CCU}$ & 18 & 29.0 & 9 & 11.4 & \\
\hline & Neurosurgery & 7 & 11.3 & 15 & 19.0 & \\
\hline & Open heart & 7 & 11.3 & 11 & 13.9 & \\
\hline & General I.C.Us & 15 & 24.2 & 24 & 30.4 & \\
\hline \multirow{5}{*}{ Age } & $20-$ & 17 & 27.3 & 14 & 17.7 & \multirow{5}{*}{0.228} \\
\hline & $25-$ & 12 & 19.4 & 20 & 25.3 & \\
\hline & $30-$ & 13 & 21.0 & 12 & 15.2 & \\
\hline & $35-$ & 15 & 24.2 & 18 & 22.8 & \\
\hline & $40+$ & 5 & 8.1 & 15 & 19.0 & \\
\hline \multirow{3}{*}{$\begin{array}{l}\text { Educational } \\
\text { qualifications }\end{array}$} & $\begin{array}{l}\text { Bachelor of science in } \\
\text { nursing }\end{array}$ & 16 & 25.8 & 20 & 25.3 & \multirow{3}{*}{0.784} \\
\hline & Technical institute diploma & 17 & 27.4 & 18 & 22.8 & \\
\hline & $\begin{array}{l}\text { Secondary nursing school } \\
\text { diploma }\end{array}$ & 29 & 46.8 & 41 & 51.9 & \\
\hline \multirow{3}{*}{$\begin{array}{l}\text { Marital } \\
\text { status }\end{array}$} & Single & 14 & 22.6 & 13 & 16.5 & \multirow{3}{*}{0.623} \\
\hline & Married & 46 & 74.2 & 64 & 81.0 & \\
\hline & Widow & 2 & 3.2 & 2 & 2.5 & \\
\hline \multirow{3}{*}{$\begin{array}{l}\text { Years of } \\
\text { experience in } \\
\text { nursing }\end{array}$} & $1-$ & 16 & 25.8 & 7 & 8.9 & \multirow{3}{*}{$0.007 *$} \\
\hline & $5-$ & 15 & 24.2 & 14 & 17.7 & \\
\hline & $10+$ & 31 & 50.0 & 58 & 73.4 & \\
\hline \multirow{3}{*}{$\begin{array}{l}\text { Years of } \\
\text { experience in } \\
\text { the nursing } \\
\text { unit }\end{array}$} & $1-$ & 22 & 35.5 & 13 & 16.5 & \multirow{3}{*}{$0.011 *$} \\
\hline & $5-$ & 16 & 25.8 & 17 & 21.5 & \\
\hline & $10+$ & 24 & 38.7 & 49 & 62.0 & \\
\hline
\end{tabular}

* Significant difference at $\mathrm{p} \leq 0.05$ 
Table (2): Head nurses transformational leadership style behavioral components as perceived by staff nurses at DNMI and AMUH hospitals (n=141).

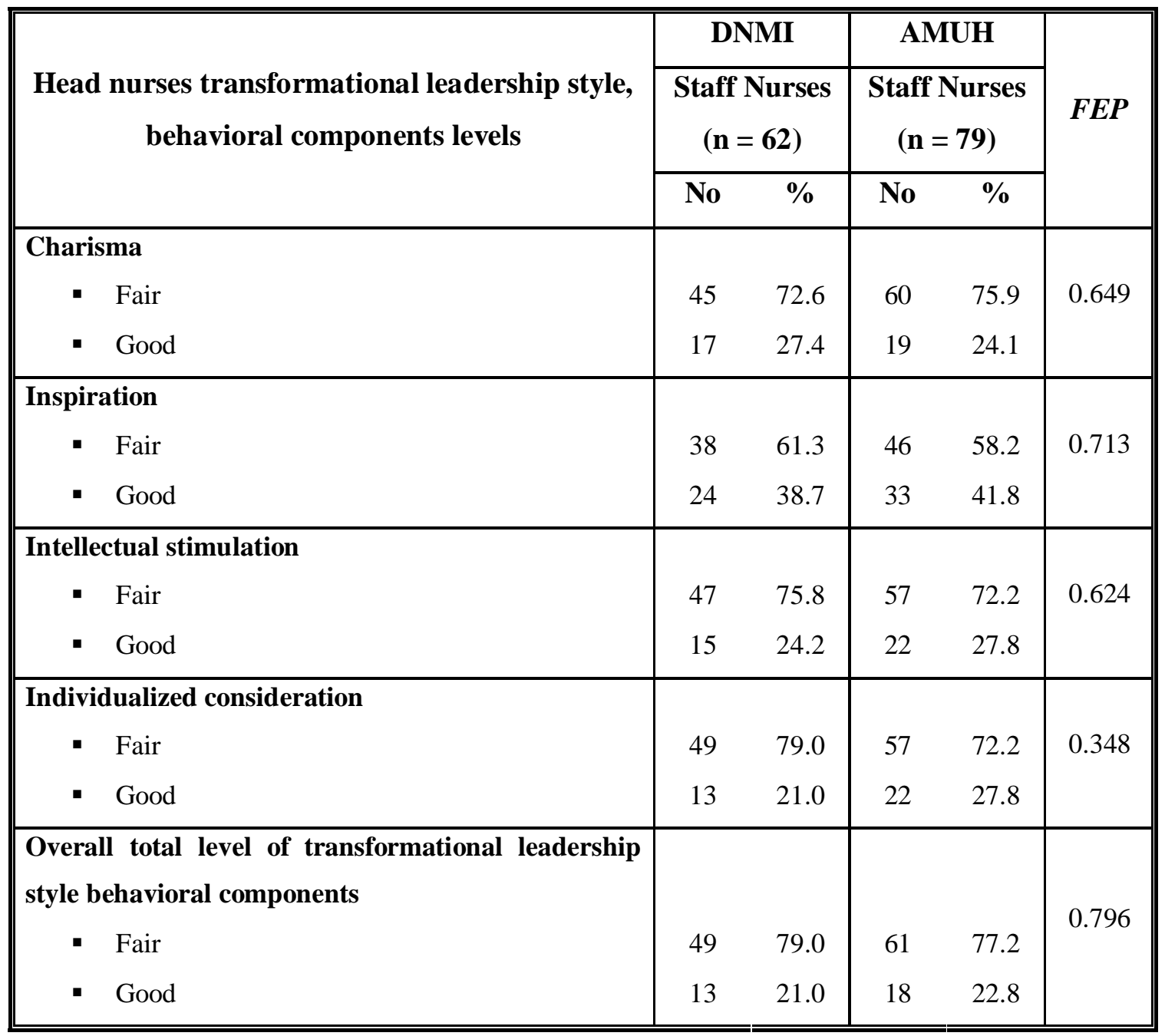

FEP: P value based on Fisher exact probability

Total mean score percent: Weak level: Score \% $<33.3 \%$,

Fair level: $33.3 \%-66.6 \%$,

Good level: Score $\%>66.6 \%$ 
Table (3): Communication climate factors as perceived by staff nurses at the DNMI and AMUH hospitals $(n=141)$.

\begin{tabular}{|c|c|c|c|c|c|}
\hline \multirow{3}{*}{$\begin{array}{l}\text { Communication climate } \\
\text { factors levels }\end{array}$} & \multirow{2}{*}{\multicolumn{2}{|c|}{$\begin{array}{c}\text { DNMI } \\
\text { Staff Nurses } \\
(\mathrm{n}=62) \\
\end{array}$}} & \multirow{2}{*}{\multicolumn{2}{|c|}{$\begin{array}{c}\text { AMUH } \\
\text { Staff Nurses } \\
(n=79)\end{array}$}} & \multirow{3}{*}{ FEP } \\
\hline & & & & & \\
\hline & No & $\%$ & No & $\%$ & \\
\hline $\begin{array}{l}\text { Communication openness } \\
\text { - Fair } \\
\text {. Good }\end{array}$ & $\begin{array}{l}53 \\
9\end{array}$ & $\begin{array}{l}85.5 \\
14.5\end{array}$ & $\begin{array}{l}65 \\
14\end{array}$ & $\begin{array}{l}82.3 \\
17.7\end{array}$ & 0.609 \\
\hline $\begin{array}{l}\text { Participation in decision making } \\
\text { - Fair } \\
\text { - Good }\end{array}$ & $\begin{array}{l}49 \\
13\end{array}$ & $\begin{array}{l}79.0 \\
21.0\end{array}$ & $\begin{array}{l}56 \\
23\end{array}$ & $\begin{array}{l}70.9 \\
29.1\end{array}$ & 0.271 \\
\hline $\begin{array}{l}\text { Information adequacy } \\
\text { - Fair } \\
\text { - } \text { Good } \\
\end{array}$ & $\begin{array}{l}56 \\
6 \\
\end{array}$ & $\begin{array}{l}90.3 \\
9.7\end{array}$ & $\begin{array}{l}63 \\
16 \\
\end{array}$ & $\begin{array}{l}79.7 \\
20.3 \\
\end{array}$ & 0.076 \\
\hline $\begin{array}{l}\text { Overall total level } \\
\text { communication climate factors. } \\
\text { - Fair } \\
\text { - } \text { Good } \\
\end{array}$ & $\begin{array}{l}55 \\
7 \\
\end{array}$ & $\begin{array}{l}88.7 \\
11.3 \\
\end{array}$ & $\begin{array}{l}64 \\
15\end{array}$ & $\begin{array}{l}81.0 \\
19.0\end{array}$ & 0.211 \\
\hline
\end{tabular}

FEP: P value based on Fisher exact probability

Total mean score percent: Weak level: Score $\%<33.3 \%$,

Fair level: $33.3 \%-66.6 \%$,

Good level: Score $\%>66.6 \%$ 
Table (4): Relationship between demographic characteristics of staff nurses and head nurses` transformational leadership style behavioral components level at DNMI $(n=62)$.

\begin{tabular}{|c|c|c|c|c|c|}
\hline \multirow{3}{*}{$\begin{array}{c}\text { Demographic characteristics of staff } \\
\text { nurses at DNMI }\end{array}$} & \multicolumn{4}{|c|}{$\begin{array}{c}\text { Head nurses transformational } \\
\text { leadership style, behavioral } \\
\text { components levels }\end{array}$} & \multirow[t]{3}{*}{$M C P$} \\
\hline & \multicolumn{2}{|c|}{ Fair } & \multicolumn{2}{|c|}{ Good } & \\
\hline & No & $\%$ & No & $\%$ & \\
\hline $\begin{array}{l}\text { Type of I.C.U } \\
\text { - Emergency dialysis } \\
\text { - Emergency care unit } \\
\text { - } \text { CCU } \\
\text { - Neurosurgery } \\
\text { - Open heart } \\
\text { - General I.C.Us } \\
\end{array}$ & $\begin{array}{l}8 \\
5 \\
16 \\
6 \\
1 \\
13 \\
\end{array}$ & $\begin{array}{l}80.0 \\
100.0 \\
88.9 \\
85.7 \\
14.3 \\
86.7 \\
\end{array}$ & $\begin{array}{l}2 \\
0 \\
2 \\
1 \\
6 \\
2\end{array}$ & $\begin{array}{l}20.0 \\
0.0 \\
11.1 \\
14.3 \\
85.7 \\
13.3 \\
\end{array}$ & $0.001 *$ \\
\hline $\begin{aligned} & \text { Age } \\
& \text {. } 20- \\
& \text { - } 25- \\
& \text { - } 30- \\
& \text { - } 35- \\
& \text { - } 40+ \\
&\end{aligned}$ & $\begin{array}{l}14 \\
10 \\
9 \\
12 \\
4 \\
\end{array}$ & $\begin{array}{l}82.4 \\
83.3 \\
69.2 \\
80.0 \\
80.0 \\
\end{array}$ & $\begin{array}{l}3 \\
2 \\
4 \\
3 \\
1 \\
\end{array}$ & $\begin{array}{l}17.6 \\
16.7 \\
30.8 \\
20.0 \\
20.0 \\
\end{array}$ & 0.908 \\
\hline $\begin{array}{l}\text { Educational Qualifications } \\
\text { - Bachelor of science in nursing } \\
\text { - Technical institute diploma } \\
\text { - Secondary nursing school diploma }\end{array}$ & $\begin{array}{l}8 \\
17 \\
24 \\
\end{array}$ & $\begin{array}{l}50.0 \\
100.0 \\
82.8 \\
\end{array}$ & $\begin{array}{l}8 \\
0 \\
5 \\
\end{array}$ & $\begin{array}{l}50.0 \\
0.0 \\
17.2 \\
\end{array}$ & $0.002 *$ \\
\hline $\begin{array}{l}\text { Marital status } \\
\text { - Single } \\
\text { - } \text { Married } \\
\text { - Widow } \\
\end{array}$ & $\begin{array}{l}10 \\
38 \\
1 \\
\end{array}$ & $\begin{array}{l}71.4 \\
82.6 \\
50.0 \\
\end{array}$ & $\begin{array}{l}4 \\
8 \\
1\end{array}$ & $\begin{array}{l}28.6 \\
17.4 \\
50.0 \\
\end{array}$ & 0.394 \\
\hline 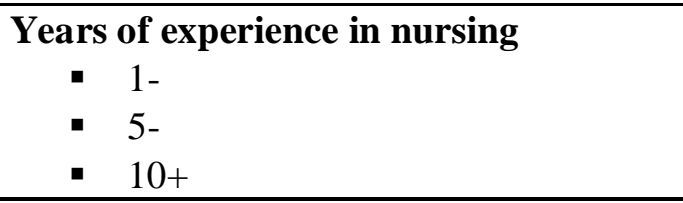 & $\begin{array}{l}13 \\
10 \\
26 \\
\end{array}$ & $\begin{array}{l}81.3 \\
66.7 \\
83.9 \\
\end{array}$ & $\begin{array}{l}3 \\
5 \\
5\end{array}$ & $\begin{array}{l}18.8 \\
33.3 \\
16.1 \\
\end{array}$ & 0.390 \\
\hline $\begin{array}{l}\text { Years of experience in the nursing unit } \\
\begin{array}{l}\text { - } 1- \\
\text { - } 5- \\
\text { - } 10+\end{array}\end{array}$ & $\begin{array}{l}17 \\
12 \\
20\end{array}$ & $\begin{array}{l}77.3 \\
75.0 \\
83.3\end{array}$ & $\begin{array}{l}5 \\
4 \\
4\end{array}$ & $\begin{array}{l}22.7 \\
25.0 \\
16.7\end{array}$ & 0.792 \\
\hline
\end{tabular}


Table (5): Relationship between demographic characteristics of staff nurses and head nurses transformational leadership style behavioral components levels at AMUH (n=79).

\begin{tabular}{|c|c|c|c|c|c|}
\hline \multirow{3}{*}{$\begin{array}{c}\text { Demographic characteristics of staff } \\
\text { nurses at AMUH }\end{array}$} & \multicolumn{4}{|c|}{$\begin{array}{c}\text { Head nurses transformational } \\
\text { leadership style, behavioral } \\
\text { components levels }\end{array}$} & \multirow[t]{3}{*}{$M C P$} \\
\hline & \multicolumn{2}{|c|}{ Fair } & \multicolumn{2}{|c|}{ Good } & \\
\hline & No & $\%$ & No & $\%$ & \\
\hline \multicolumn{6}{|l|}{ Type of I.C.U } \\
\hline - Emergency dialysis & 6 & 100.0 & 0 & 0.0 & \multirow{6}{*}{0.087} \\
\hline - Emergency care unit & 10 & 71.4 & 4 & 28.6 & \\
\hline - $\mathrm{CCU}$ & 7 & 77.8 & 2 & 22.2 & \\
\hline - Neurosurgery & 13 & 86.7 & 2 & 13.3 & \\
\hline - Open heart & 5 & 45.5 & 6 & 54.5 & \\
\hline - General I.C.Us & 20 & 83.3 & 4 & 16.7 & \\
\hline \multicolumn{5}{|l|}{ Age } & \multirow{6}{*}{0.747} \\
\hline - $20-$ & 10 & 71.4 & 4 & 28.6 & \\
\hline - $25-$ & 16 & 80.0 & 4 & 20.0 & \\
\hline - $30-$ & 10 & 83.3 & 2 & 16.7 & \\
\hline - $35-$ & 15 & 83.3 & 3 & 16.7 & \\
\hline - $40+$ & 10 & 66.7 & 5 & 33.3 & \\
\hline \multicolumn{5}{|l|}{ Educational Qualifications } & \multirow{4}{*}{0.312} \\
\hline - Bachelor of science in nursing & 13 & 65.0 & 7 & 35.0 & \\
\hline - Technical institute diploma & 15 & 83.3 & 3 & 16.7 & \\
\hline - Secondary nursing school diploma & 33 & 80.5 & 8 & 19.5 & \\
\hline \multicolumn{5}{|l|}{ Marital status } & \multirow{4}{*}{$0.012 *$} \\
\hline - Single & 6 & 46.2 & 7 & 53.8 & \\
\hline - Married & 53 & 82.8 & 11 & 17.2 & \\
\hline - Widow & 2 & 100.0 & 0 & 0.0 & \\
\hline \multicolumn{5}{|l|}{ Years of experience in nursing } & \multirow{4}{*}{0.164} \\
\hline - $1-$ & 4 & 57.1 & 3 & 42.9 & \\
\hline - $5-$ & 13 & 92.9 & 1 & 7.1 & \\
\hline - $10+$ & 44 & 75.9 & 14 & 24.1 & \\
\hline \multirow{3}{*}{ 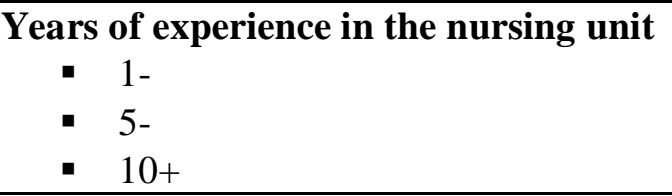 } & 10 & 76.9 & 3 & 23.1 & \multirow{3}{*}{0.845} \\
\hline & 14 & 82.4 & 3 & 17.6 & \\
\hline & 37 & 75.5 & 12 & 24.5 & \\
\hline
\end{tabular}

MCP: P value based on Mont Carlo exact probability

$* \mathrm{P}<0.05$ (significant) 
Table (6): Relationship between demographic characteristics of staff nurses and level of communication climate factors levels DNMI $(n=62)$.

\begin{tabular}{|c|c|c|c|c|c|}
\hline \multirow{3}{*}{$\begin{array}{c}\text { Demographic characteristics of staff } \\
\text { nurses at DNMI }\end{array}$} & \multicolumn{4}{|c|}{ Communication climate level } & \multirow{3}{*}{$M C P$} \\
\hline & \multicolumn{2}{|c|}{ Fair } & \multicolumn{2}{|c|}{ Good } & \\
\hline & No & $\%$ & No & $\%$ & \\
\hline \multicolumn{6}{|l|}{ Type of I.C.U } \\
\hline - Emergency dialysis & 10 & 100.0 & 0 & 0.0 & \multirow{6}{*}{$0.001 *$} \\
\hline - Emergency care unit & 5 & 100.0 & 0 & 0.0 & \\
\hline - $\mathrm{CCU}$ & 18 & 100.0 & 0 & 0.0 & \\
\hline - Neuro surgery & 6 & 85.7 & 1 & 14.3 & \\
\hline - Open heart & 2 & 28.6 & 5 & 71.4 & \\
\hline - General I.C.Us & 14 & 93.3 & 1 & 6.7 & \\
\hline \multicolumn{5}{|l|}{ Age } & \multirow{6}{*}{0.868} \\
\hline - $20-$ & 16 & 94.1 & 1 & 5.9 & \\
\hline - $25-$ & 11 & 91.7 & 1 & 8.3 & \\
\hline - $30-$ & 11 & 84.6 & 2 & 15.4 & \\
\hline - $35-$ & 13 & 86.7 & 2 & 13.3 & \\
\hline - $40+$ & 4 & 80.0 & 1 & 20.0 & \\
\hline \multicolumn{5}{|l|}{ Educational Qualifications } & \multirow{4}{*}{$0.050 *$} \\
\hline - Bachelor of science in nursing & 12 & 75.0 & 4 & 25.0 & \\
\hline - Technical institute diploma & 17 & 100.0 & 0 & 0.0 & \\
\hline - Secondary nursing school diploma & 26 & 89.7 & 3 & 10.3 & \\
\hline \multicolumn{5}{|l|}{ Marital status } & \multirow{4}{*}{0.180} \\
\hline - Single & 12 & 85.7 & 2 & 14.3 & \\
\hline - Married & 42 & 91.3 & 4 & 8.7 & \\
\hline - Widow & 1 & 50.0 & 1 & 50.0 & \\
\hline \multirow{4}{*}{$\begin{array}{l}\text { Years of experience in nursing } \\
\begin{array}{l}\text { - } 1- \\
\text { - } 5- \\
\text { - } 10+\end{array}\end{array}$} & & & & & \multirow{4}{*}{0.444} \\
\hline & 15 & 93.8 & 1 & 6.3 & \\
\hline & 12 & 80.0 & 3 & 20.0 & \\
\hline & 28 & 90.3 & 3 & 9.7 & \\
\hline \multirow{3}{*}{ 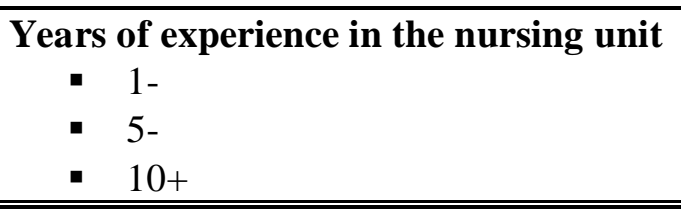 } & 20 & 90.9 & 2 & 9.1 & \multirow{3}{*}{0.921} \\
\hline & 14 & 87.5 & 2 & 12.5 & \\
\hline & 21 & 87.5 & 3 & 12.5 & \\
\hline
\end{tabular}

MCP: P value based on Mont Carlo exact probability

$* \mathrm{P}<0.05$ (significant) 
Table (7): Relationship between demographic characteristics of staff nurses and level of communication climate factors levels AMUH $(n=79)$.

\begin{tabular}{|c|c|c|c|c|c|}
\hline \multirow{3}{*}{$\begin{array}{c}\text { Demographic characteristics of staff } \\
\text { nurses at AMUH }\end{array}$} & \multicolumn{4}{|c|}{ Communication climate levels } & \multirow{3}{*}{$M C P$} \\
\hline & \multicolumn{2}{|c|}{ Fair } & \multicolumn{2}{|c|}{ Good } & \\
\hline & No & $\%$ & No & $\%$ & \\
\hline $\begin{array}{l}\text { Type of I.C.U } \\
\text { - Emergency dialysis } \\
\text { - Emergency care unit } \\
\text { - CCU } \\
\text { - Neurosurgery } \\
\text { - Open heart } \\
\text { - General I.C.Us } \\
\end{array}$ & $\begin{array}{c}6 \\
11 \\
6 \\
14 \\
6 \\
21 \\
\end{array}$ & $\begin{array}{l}100.0 \\
78.6 \\
66.7 \\
93.3 \\
54.5 \\
87.5 \\
\end{array}$ & $\begin{array}{l}0 \\
3 \\
3 \\
1 \\
5 \\
3\end{array}$ & $\begin{array}{c}0.0 \\
21.4 \\
33.3 \\
6.7 \\
45.5 \\
12.5 \\
\end{array}$ & 0.081 \\
\hline $\begin{array}{ll}\text { Age } & \\
\text { - } & 20- \\
\text { - } & 25- \\
\text { - } & 30- \\
\text { - } & 35- \\
\text { - } & 40+ \\
\end{array}$ & $\begin{array}{c}11 \\
17 \\
9 \\
15 \\
12 \\
\end{array}$ & $\begin{array}{l}78.6 \\
85.0 \\
75.0 \\
83.3 \\
80.0 \\
\end{array}$ & $\begin{array}{l}3 \\
3 \\
3 \\
3 \\
3 \\
\end{array}$ & $\begin{array}{l}21.4 \\
15.0 \\
25.0 \\
16.7 \\
20.0 \\
\end{array}$ & 0.961 \\
\hline $\begin{array}{l}\text { Educational Qualifications } \\
\text { - Bachelor of science in nursing } \\
\text { - Technical institute diploma } \\
\text { - Secondary nursing school diploma }\end{array}$ & $\begin{array}{l}12 \\
16 \\
36 \\
\end{array}$ & $\begin{array}{l}60.0 \\
88.9 \\
87.8 \\
\end{array}$ & $\begin{array}{l}8 \\
2 \\
5 \\
\end{array}$ & $\begin{array}{l}40.0 \\
11.1 \\
12.2 \\
\end{array}$ & $0.021 *$ \\
\hline $\begin{array}{l}\text { Marital status } \\
\text { - Single } \\
\text { - Married } \\
\text { - Widow } \\
\end{array}$ & $\begin{array}{c}5 \\
57 \\
2\end{array}$ & $\begin{array}{c}38.5 \\
89.1 \\
100.0\end{array}$ & $\begin{array}{l}8 \\
7 \\
0\end{array}$ & $\begin{array}{c}61.5 \\
10.9 \\
0.0 \\
\end{array}$ & $0.001 *$ \\
\hline 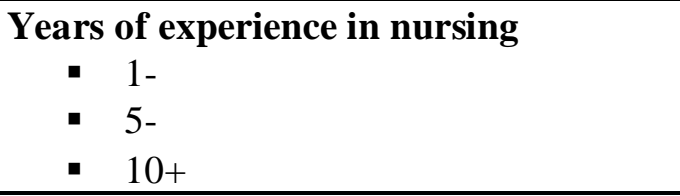 & $\begin{array}{c}5 \\
11 \\
48 \\
\end{array}$ & $\begin{array}{l}71.4 \\
78.6 \\
82.8 \\
\end{array}$ & $\begin{array}{c}2 \\
3 \\
10 \\
\end{array}$ & $\begin{array}{l}28.6 \\
21.4 \\
17.2 \\
\end{array}$ & 0.746 \\
\hline 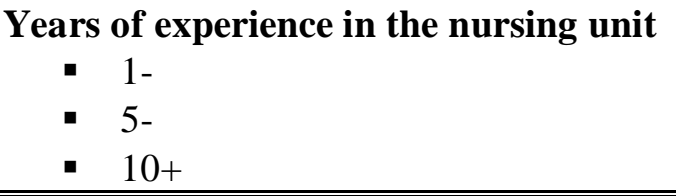 & $\begin{array}{l}11 \\
13 \\
40 \\
\end{array}$ & $\begin{array}{l}84.6 \\
76.5 \\
81.6 \\
\end{array}$ & $\begin{array}{l}2 \\
4 \\
9 \\
\end{array}$ & $\begin{array}{l}15.4 \\
23.5 \\
18.4 \\
\end{array}$ & 0.839 \\
\hline
\end{tabular}

MCP: P value based on Mont Carlo exact probability

$* \mathrm{P}<0.05$ (significant) 
Table (8): Relationship between demographic characteristics of staff nurses and level of communication climate factors levels DNMI $(n=62)$.

\begin{tabular}{|c|c|c|c|c|c|}
\hline \multirow{3}{*}{$\begin{array}{c}\text { Demographic characteristics of staff } \\
\text { nurses at DNMI }\end{array}$} & \multicolumn{4}{|c|}{ Communication climate level } & \multirow{3}{*}{$M C P$} \\
\hline & \multicolumn{2}{|c|}{ Fair } & \multicolumn{2}{|c|}{ Good } & \\
\hline & No & $\%$ & No & $\%$ & \\
\hline \multicolumn{6}{|l|}{ Type of I.C.U } \\
\hline - Emergency dialysis & 10 & 100.0 & 0 & 0.0 & \multirow{6}{*}{$0.001 *$} \\
\hline - Emergency care unit & 5 & 100.0 & 0 & 0.0 & \\
\hline - $\mathrm{CCU}$ & 18 & 100.0 & 0 & 0.0 & \\
\hline - Neuro surgery & 6 & 85.7 & 1 & 14.3 & \\
\hline - Open heart & 2 & 28.6 & 5 & 71.4 & \\
\hline - General I.C.Us & 14 & 93.3 & 1 & 6.7 & \\
\hline \multicolumn{5}{|l|}{ Age } & \multirow{6}{*}{0.868} \\
\hline - $20-$ & 16 & 94.1 & 1 & 5.9 & \\
\hline - $25-$ & 11 & 91.7 & 1 & 8.3 & \\
\hline - $30-$ & 11 & 84.6 & 2 & 15.4 & \\
\hline - $35-$ & 13 & 86.7 & 2 & 13.3 & \\
\hline - $40+$ & 4 & 80.0 & 1 & 20.0 & \\
\hline \multicolumn{5}{|l|}{ Educational Qualifications } & \multirow{4}{*}{$0.050 *$} \\
\hline - Bachelor of science in nursing & 12 & 75.0 & 4 & 25.0 & \\
\hline - Technical institute diploma & 17 & 100.0 & 0 & 0.0 & \\
\hline - Secondary nursing school diploma & 26 & 89.7 & 3 & 10.3 & \\
\hline \multicolumn{5}{|l|}{ Marital status } & \multirow{4}{*}{0.180} \\
\hline - Single & 12 & 85.7 & 2 & 14.3 & \\
\hline - Married & 42 & 91.3 & 4 & 8.7 & \\
\hline - Widow & 1 & 50.0 & 1 & 50.0 & \\
\hline \multirow{4}{*}{$\begin{array}{l}\text { Years of experience in nursing } \\
\begin{array}{l}\text { - } 1- \\
\text { - } 5- \\
\text { - } 10+\end{array}\end{array}$} & & & & & \multirow{4}{*}{0.444} \\
\hline & 15 & 93.8 & 1 & 6.3 & \\
\hline & 12 & 80.0 & 3 & 20.0 & \\
\hline & 28 & 90.3 & 3 & 9.7 & \\
\hline \multirow{3}{*}{ 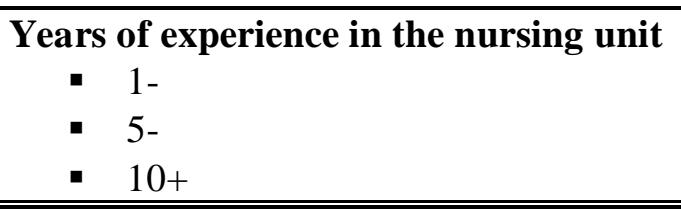 } & 20 & 90.9 & 2 & 9.1 & \multirow{3}{*}{0.921} \\
\hline & 14 & 87.5 & 2 & 12.5 & \\
\hline & 21 & 87.5 & 3 & 12.5 & \\
\hline
\end{tabular}

MCP: P value based on Mont Carlo exact probability

$* \mathrm{P}<0.05$ (significant) 
Table (9): Correlation Matrix between transformational leadership style behavioral components and communication climate factors at the DNMI and AMUH hospitals $(n=141)$.

\begin{tabular}{|c|c|c|c|c|c|}
\hline \multirow[b]{2}{*}{ Hospitals } & \multirow{2}{*}{$\begin{array}{c}\text { Leadership style } \\
\text { behavioral } \\
\text { components }\end{array}$} & \multicolumn{3}{|c|}{ Communication climate factors } & \multirow{2}{*}{$\begin{array}{l}\text { Communication } \\
\text { climate total }\end{array}$} \\
\hline & & $\begin{array}{c}\text { Communication } \\
\text { openness }\end{array}$ & $\begin{array}{l}\text { Participation in } \\
\text { decision making }\end{array}$ & $\begin{array}{c}\text { Information } \\
\text { adequacy }\end{array}$ & \\
\hline \multirow{5}{*}{ DNMI } & Charisma & $0.66 *$ & $0.43 *$ & $0.66 *$ & $0.68 *$ \\
\hline & Inspiration & $0.74 *$ & $0.51 *$ & $0.71 *$ & $0.76 *$ \\
\hline & $\begin{array}{l}\text { Intellectual } \\
\text { stimulation }\end{array}$ & $0.72 *$ & $0.46^{*}$ & $0.71 *$ & $0.73 *$ \\
\hline & $\begin{array}{l}\text { Individualized } \\
\text { consideration }\end{array}$ & $0.71 *$ & $0.46^{*}$ & $0.71 *$ & $0.73 *$ \\
\hline & $\begin{array}{l}\text { Leadership style } \\
\text { overall }\end{array}$ & $0.73 *$ & $0.47 *$ & $0.72 *$ & $0.75 *$ \\
\hline \multirow{5}{*}{ AMUH } & Charisma & $0.59 *$ & $0.43 *$ & $0.65 *$ & $0.64 *$ \\
\hline & Inspiration & $0.50 *$ & $0.38 *$ & $0.62 *$ & $0.57 *$ \\
\hline & $\begin{array}{l}\text { Intellectual } \\
\text { stimulation }\end{array}$ & $0.60 *$ & $0.42 *$ & $0.64 *$ & $0.64 *$ \\
\hline & $\begin{array}{l}\text { Individualized } \\
\text { consideration }\end{array}$ & $0.64 *$ & $0.49 *$ & $0.68 *$ & $0.69 *$ \\
\hline & $\begin{array}{l}\text { Leadership style } \\
\text { overall }\end{array}$ & $0.64 *$ & $0.47 *$ & $0.70 *$ & $0.69 *$ \\
\hline
\end{tabular}

* Significant correlation coefficient Interpretation of correlation 


\section{References}

1. Simola S, Barling J, Turner N. Transformational Leadership and Leaders' Mode of Care Reasoning. Journal of Business Ethics 2012; 108, 229-37.

2. Ingram D, Media D. Transformational leadership VS transactional leadership definition. Hearst Newspapers, LLC. 2015; Available at: http://smallbusiness.chron,com/transfor mational-leasership VS-transactionalleadership-difintion-13834-html.

3. Bass B, Avolio J. Improving Organizational Effectiveness through Transformational Leadership. California: Sage Publication Inc., 1994; 104-20.

4. Bass B, Riggio E. Transformational leadership. Mahwah, New Jersey, Laurence Erlbsum Associates, Inc. 2008;

5. Murphy L. Transformational leadership: a cascading chain reaction Journal of Nursing Management 2005; 13, 12836.

6. Gift V, Frans C. Effective transformational leadership behaviors for managing change. Journal of Human Resource Management 2006; 4(2), 1-9.

7. Ronald A. Leading with an Open Heart. Leadership Essentials 2006; 3(1):1520.

8. Byrne A, Rees R. The Successful Leadership Development Program: How to Build It and How to Keep It Going. $2^{\text {nd }}$ ed. San Francisco: John Wiley \& Sons, Inc., 2006; 45-8.

9. Charbonnier A, Akremi A. A multivariate model of transformational leadership and adaptive performance and the moderating role of climate for innovation. Group and Organization Management 2010; 35(6), 699-726.
10. Cyprus S. What is the communication climate. 2015; conjecture corporation. Available at: www.wiseegeek.com/isthe-communicationcliamte.htm.

Retrieved on: 20/1/2015.

11. Nordin S, Sivaplan S. Hashim H, Ahmad W, Abdullah A. Organizational communication climate and conflict management communications management in an oil and gas company. $2^{\text {nd }}$ world conference on business, economics and management 2013; Procedia social and behavioral science 1046-59.

12. Mack S. What is a communication climate in business, hearts news papers, LLC. 2015; Available at: smallbusiness.chron.com/../cationclimate.business.

13. Costigan J, Schmeidler M. The communication climate inventory The Pfeiffer book of successful communication skill- building tools Available at: https://www.safaribooksonline.com/libr ary/view/the-pfeifferbook/9780470181805/ch31.html.univer sityassociation.,Inc.1984.

14. Costigan J, Schmeidler M. Annual; developing human resources part 2 creating effective work groups 1984; Pfeiffer \& company, San Diego California.

15. Kristy R. communication climate in healthcare setting: a case study. 1992; scholar achieve @ OSU. Available at: http://hdl.handle.net/.

16. Haider J, Ali A. Impact of internal organizational communications on employee job satisfaction-case of some Pakistani Banks. Journal of Management and business Studies 2012; 1(2): 38-44.

17. Mustafa B. Influence of leadership styles on communication climate: a case 
study of maderasahs management in Singapore 2009. Published Master Thesis. Interracial Islamic University Malaysia.

18. The communication blog: communication strategies: openness. Available at: http//tcbdevito.blogspot.com/2011/11/c omunication-strategies-openess.html.

19. Bartle P. Participatory management: Methods to increase staff input in organizational decision making. 2012; Available at: http://cec.vcn.bc.ca/cmp/modeles/pmpm,htm.

20. Harris T, Nelson M. Applied organizational communication theory and practice in a global Taylor and Francis 1981; $342-46$.

21. Camelo SH. Professional Competences of Nurse to Work in Intensive Care Units. Latino- Am. En her magen. 2012; 20(1): 192-200. Available at: www. Eerp.usp.br/ratae.

22. Liceo H, Chuange A. Transforming Service Employees and Climate: a Multilevel, Multisource of Transformational Leadership in Building Long-term Service Relationships. Journal of Applied Psychology 2007; 1006-19.

23. Czech K, Forward L. Leader communication: Faculty perceptions of the department chair. Communication Quarterly 2010; 58(4), 431-57.

24. Gross R. The impact of transformational leadership, climate and trust in crossfunctional teams. International Journal of recent advances in organizational behavior and decision science. 2014; 1 (2): 22-6.

25. Gheith N AR. Reconstructing organization culture through enforcing head nurses transformational leadership style. Australian Journal of basic and applied sciences. 2010; 4(6): 12881296.

26. Mohamed FR, Abdallah SM, AboElmaged NS. Communication Climate at Main Assiut University Hospital. Journal of American Science 2013; 9 (12) 292-303.

27. Moustafa WH. The effect of transformational leadership style training program for head nurses on the quality of work life of staff nurses. Faculty of Nursing, University of Alexandria, Published Doctoral Thesis 2013.

28. Bass B. (1995) Leadership Beyond Expectations. In: Shortell S, Kaluzny A. Health Care Management: Organization Design and Behavior. 3rd ed. Canada: Dalmar Publishers, 1999; 95-100.

29. Nurlita I. Investigation of organizational communication climate at BhayanGkara Surabaya University using communication climate inventory (CCI) method. SAVAP international 2012; 3(2). Available at www.Journals. savap.org.pk.

30. Costigan J, Schmeidler M. Inventories, questionnaires, and surveys communication. The Pfeiffer library vol 5 second edition 1998; JosseyBass/Pfeiffer.

31. Donald p. John J. Satisfaction in Taiwan High- Tech industry: A personality traits study 1988. "Communication climate, job satisfaction and organizational commitment. The effect of information adequacy, communication openness and decision participation".

32. Trombelta J. Rogers D. The effect of information adequacy, communication openness, and decision participation. 1998; Management communication quarterly. I. 494-514. 
33. Men L. Why leadership matters to internal communication; linking transformational leadership, symmetrical communication and employee outcomes: Journal of public relations research. 2014; 26 (3): 256-79.

34. Kathleen C, Forward L. Communication, Leadership, and Job Satisfaction: Perspectives on Supervisor-Subordinate Relationships. Studies in Media and Communication. December 2013; 1(2): 112-34.

35. Kanungo N., Mendonca M. Ethical dimensions of leadership. Thousand Oaks: Sage. (1996).

36. Avolio B.J, Bhatia P, Zhu W. Transformational Leadership and organizational Commitment: Mediating Role of Psychological Empowerment and Moderating Role of Structural Distance. Journal of Organizational Behavior 2004; 25: 951- 68.

37. Callow N. Measurement of Transformational Leadership and Its Relationship with Team Cohesion and Performance Level. Journal of Applied Sport Psychology 2009; 21: 395-412.

38. Leithwood K (2000). The effect of transformational leadership on organizational conditions and student engagement with school. Journal of Educational Administration 38(2): 11223.

39. Stone A, Russell R, Patterson K. Transformational verses servant leadership a difference in leader focus, servant leadership round table - October 2003. Available at: http://www.regent.edu/acad/cls/2003ser vantleadershiproundtable/stone.pdf. Retrieved on: 2006.

40. Avolio J, Bass B. Developing potential across a full range of leadership: cases on transactional and transformational leadership. Mahwah, NJ: Lawrence Erlbaum Associates, Inc. 2002; 789-99

41. Barge JK. Psychological and discursive leadership approaches to context. Paper presented at the meeting of the national communication association 2008, Boston, MA.

42. Hackman Z, Johnson E. Leadership a communication perceptive. $5^{\text {th }}$ ed. Long Grove IL; Wave land Press.2009; 25989.

43. Bomal L, Deal T. Reforming Organizations: Artistry, choice and leadership. $2^{\text {nd }}$ ed. Jossey-Bass, 1997;4367.

44. Mohammed R, Hussein A. The $8^{\text {th }}$ International Conference on Knowledge, Culture and Change in Organizations. August 2008. Cambridge University, United Kingdom.

45. Sheridan J, Vredenburgh D, Abelson M. Contextual Model of Leadership Influence in Hospital Units. Academy of Management Journal 1984; 27(1):5778.

46. Mitchell S. American Generations: Who They Are. How They Live. What they Think. $3^{\text {rd }}$ ed. Ithaca, N.Y: New Strategic Publications, Inc. 2000; 456-67.

47. Nguyen A, Taylor J, Bradley S. Relative Pay and Job Satisfaction: Some New Evidence. 2003. Available at: http://www.lums.lancs.ac.uk/publications Retrieved on: 8/1/2015.

48. Mostafa W. The Relation Between Head Nurses Leadership Styles and Their Nurses` Job Satisfaction. Unpublished Master Thesis. Faculty of Nursing. Alexandria University. 2005.

49. Liao H, Chuang A. Transforming service employees and climate: A multi level, multisource examination of transformational leadership building 
long-term service relationships. 2007; Journal of Applied Psychology 92, 1006-1019.

50. Dvir T, Eden D, Avalio B, Shamir B. Impact of transformational leadership on follower development and performance: 2002; a field experiment academy of management journal 45 (4): 735-744.

51. Brown W, May D. Organizational change and development the efficacy of transformational leadership, training. 2012; Journal of management development 31(6): 520-536. 